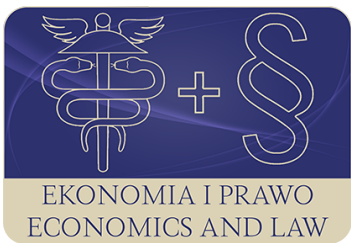

EKONOMIA I PRAWO. ECONOMICS AND LAW

Volume 19, Issue 4, December 2020

p-ISSN 1898-2255, e-ISSN 2392-1625

www.economicsandlaw.pl

ORIGINAL ARTICLE

received 17.03.2020; revised 25.06.2020; accepted 31.12.2020

Citation: Butor-Keler, A., \& Polasik, M.(2020). The role of regulatory sandboxes in the development of innovations on the financial services market: the case of the United Kingdom. Ekonomia $i$ Prawo. Economics and Law, 19(4): 621-638. doi:10.12775/EiP.2020.041.

\title{
The role of regulatory sandboxes in the development of innovations on the financial services market: the case of the United Kingdom
}

\section{AGNIESZKA BUTOR-KELER}

corresponding author

Warsaw School of Economics, Collegium of Business Administration, Institute of Corporate Finance and Investment, al. Niepodległości 162, 02-554 Warszawa, Poland

$\square$ butor.agnieszka@gmail.com

(D) orcid.org/0000-0002-2761-3144

\section{MICHAE POLASIK}

Nicolaus Copernicus University in Torun, Faculty of Economic Sciences and Management, Department of Digital Economy and Finance, Poland

$\square$ michal.polasik@umk.pl

(iD) orcid.org/0000-0002-7790-4839

\begin{abstract}
Motivation: The dynamic development of innovation in the financial market and the process of globalisation were at the heart of creating a new financial technology sector, called FinTech. In order to allow for a safe and intensive development of innovations and create opportunities for all entities, including start-ups, state supervisors and regulators create dedicated market environments - regulatory sandboxes.

Aim: (1) to define the concept of a regulatory sandbox; (2) to identify the forms of support for innovative solutions in the financial market; (3) to identify the outcomes of a regulato-

ry sandbox in the case of the United Kingdom.

Results: Regulatory sandboxes are a new supervisory tool which, despite only a few years of history, has gained recognition of financial market participants. Research has shown that a regulatory sandbox has many benefits not only for the companies joining it but also for the supervisory institution. Sandboxes allow participants to receive con-
\end{abstract}


tinuous substantive support, obtain licences faster and resolve legal doubts. Participation

in a regulatory sandbox is also a form of promotion and facilitates raising investment

capital. On the other hand, regulatory sandboxes are still in the early stages of development, and the support they provide is limited. Some companies also experience problems in dealing with the long and complicated process of applying for admission and the limited number of participants. The latter obstacle may result in unequal competition on the market and failure to fully exploit the development potential of FinTech. The most important benefit for a supervisor is that through its engagement in a regulatory sandbox, it gains additional knowledge of new technologies and new business models, and its employees develop important competences. The dialogue conducted with professional financial market participants allows for a better assessment of the risks associated with new technologies. The first outcomes of participation in a regulatory sandbox are encouraging for new innovative players and supervisory authorities. It is recommended that this initiative be extended in order to enable more market players to conduct testing.

Keywords: regulatory sandbox; FinTech; financial market; innovation JEL: E42; G11; G21; O33

\section{Introduction}

In order to interpret the term 'FinTech' correctly, we should refer to several definitions. For instance, the Financial Stability Board (FSB, 2020) defines FinTech as: "technologically enabled innovation in financial services that could result in new business models, applications, processes or products with an associated material effect on financial markets and institutions and the provision of financial services. FinTech innovations are poised to affect many different areas of financial services in the coming years'. This definition was also referred to by the EBA (2017) in the Discussion paper on the EBA's approach to financial technology (FinTech).

Philippon (2016, p. 2) defines FinTech as follows: 'FinTech covers digital innovations and technology-enabled business model innovations in the financial sector'. Gai et al. (2018), on the other hand, indicate that the FinTech concept covers a range of phenomena, from the provision of financial services to the characteristics of financial innovation. The authors claim that FinTech is a relatively new topic in the financial industry, but it is constantly growing in popularity. It should be noted, however, that the term itself is not new; it was used for the first time as early as 1972 by Bettinger in relation to new financial technologies (Bunea et al., 2016).

FinTech definitions tend to focus on the material aspects of financial services and not the entities involved. This is understandable because FinTech is a very broad concept and combines financial innovation in many narrower areas, such as payments (Polasik \& Piotrowski, 2016), banking, loans, robo-advisors, cryptoassets, blockchain solutions (Du et al., 2019), insurance. Some of these areas have even been branded, e.g. the sector focused on online lending - LendTech, the sector focused on innovation in insurance - InsurTech (Alt et al., 2018). A definition of FinTech was proposed by Harasim \& Mitręga-Niestrój 
(2018), who defined FinTech in both broad and narrow terms. 'In broad terms, FinTech means using innovative technologies to provide existing financial services more efficiently'. In narrow terms, 'FinTech is a financial services sector created by non-traditional financial services providers that uses innovative technologies to provide existing financial services more efficiently and create new ones to deliver new value to customers'. Another narrow definition was proposed by McAuley (2015) who considered FinTech to be 'an economic industry composed of companies that use technology to make financial systems more efficient'. Szpringer (2016) emphasises that FinTech provides an opportunity to transform the entire financial sector, regulations, and business models known thus far. FinTech combines traditional financial services and new technologies using large amounts of data.

Developing innovation is not an easy task, as it involves the need to comply with the legal regime (often not adapted to the use of new technologies), supervisory requirements and frequent copying of ideas by larger and more experienced players. Moreover, innovations are typically created by new companies, start-ups, that do not have a large financial base, unlike banks for example. Therefore, they have serious difficulties in meeting regulatory requirements, including capital requirements. This is why supervisors develop many financial innovation support programmes, such as the Innovation Hub (KNF, 2020), acceleration programmes, sandboxes, and others. Although these initiatives are aimed at both supervised and unsupervised entities, they are more often used by unsupervised entities. The complexity of the issue of legal and market tools supporting the development of innovation in the financial services market, including regulatory sandboxes, undoubtedly requires scientific considerations, the results of which are presented in this work.

The objectives of the present paper are: (1) to define the concept of a regulatory sandbox; (2) to identify the forms of support for innovative solutions in the financial market; (3) to identify the outcomes of a regulatory sandbox in the case of the United Kingdom.

\section{Regulatory sandboxes as part of financial innovation development worldwide: literature review}

Technological innovations play an important role in economic development and building competitive advantage. Regulators and supervisors around the world are fully aware that it is crucial to transform the financial sector, both locally and globally.

Models of regulatory sandboxes in the financial services market do not have a long tradition (Marchewka-Bartkowiak, 2020). It is accepted that sandboxes are closely related to the FinTech industry, but they had already been used for other industries, e.g. for testing computer games (Ocio \& Brugos, 2009), IT environments (Junglas \& Steel, 2007), or experimental medicines (Marchewka-Bartkowiak, 2019). Within the proposed definitions, researchers have tried 
to cover different aspects of this phenomenon. The aspect of an experiment was emphasised, e.g., by Ringe \& Rouf (2018): 'Regulatory sandbox — an experimentation space - as a step towards a regulatory environment where such new business models can thrive'. Attention was also drawn to the lowered barriers to entry on the market. Guo \& Liang (2016) argued that 'the sandbox delineates a restricted scope with simplified market access standards and procedures'. Notably, the terms 'regulatory sandbox' and 'virtual sandbox' should not be equated. Virtual sandboxes allow participants to test products without entering the real market (Jenik \& Lauer, 2017). This means that consumers who take part in tests in a virtual sandbox use, for instance, virtual funds.

Taking the above into account, the authors have proposed a definition, stating that a regulatory sandbox is a restricted, experimental market environment that is usually created by state regulators of supervisors. The purpose of regulatory sandboxes is to create a safe, dedicated space where entrepreneurs, including small start-ups, can test innovative products, technologies, or models with constant support and supervision. An additional advantage is the development of new products that can be used by customers. Testing of products in a regulatory sandbox is ultimately intended to lead the participant to obtaining permissions, licences, e.g. to operate in the financial services market.

It is generally accepted that it was the UK's Financial Conduct Authority (hereinafter: the FCA) that initiated the idea of regulatory sandboxes worldwide. However, this statement is not entirely correct, as this trend was started by the US Consumer Financial Protection Bureau (CFPB, 2012) in 2012, based on Project Catalyst. However, the claim that the use of the term 'regulatory sandbox' in 2015 was initiated and spread by the FCA is true. The FCA (2015) has spread the regulatory sandbox concept, thus responding to the dynamic development of the financial market. In Europe, the FCA was swiftly followed by the Netherlands, i.e. the Financial Markets Authority (AFM) and the De Nederlandsche Bank (DNB), which implemented a regulatory sandbox in 2016 (De Brauw Blackstone Westbroek, 2016). Active supervisors with regulatory sandboxes also include: the Australian Securities and Investments Commission (ASIC), the Monetary Authority of Singapore, the Hong Kong Monetary Authority, or the Bank of Lithuania (Columbia Institute for Tele-Information, 2020).

Sandboxes are also to be a response to insufficient legal regulations in the area of innovative FinTech entities. Regulation largely lags behind dynamic technological progress or standardises the market to such an extent that the entry of innovative players can be significantly hindered. This is also stressed by Laahanen \& Yrjänä (2019): 'the problem is that regulations do not keep pace with technological innovations, as technological innovations develop far faster than applicable regulations. Regulations have failed to meet the demands of fintech companies, hence technology-driven regulations will respond to the risks of fintechs'. 
Creating regulatory sandboxes requires supervisors and regulators to be mature. The approach to innovation varies from one jurisdiction to another and it is not always possible to reach an internal consensus on solutions in this area. It is worth remembering that innovations distort the traditional system of large, secure financial institutions which for a long time have been synonymous with institutions of public trust (Romanova et al., 2018). Start-ups try to compete with large financial institutions (Jagtiania \& Lemieux, 2018). The break with safe financial services built over the years, especially those regulated after the financial crisis, raises many concerns. They relate primarily to the safety of financial markets and market participants and the lack of security and guarantees for consumers, e.g. in the form of the Bank Guarantee Fund ${ }^{1}$ (BFG, 2019).

Until recently, few people imagined that a start-up comprising several people could open in the financial market. However, such situations are not impossible - for instance, CommonBond (2020) is a start-up established by four friends in 2012. The company deals with cheap loans for students on more favourable conditions than traditional market ones. CommonBond has already disbursed loans exceeding a total of USD 3 billion, financing them with bonds. The innovations created are usually a response to needs and an attempt to change the market situation. That is also what happened in that case. The originators, annoyed with the high cost of loans taken out by students, decided to change the traditional product. Knowing the problem, they wanted to create favourable conditions for students at the beginning of their paths. The company has been gradually developing; additionally, it participates in educational programs, e.g. covering the costs of education of children in developing countries.

The whole process is beneficial primarily to consumers, who gain access to an increasing range of dedicated products, offered at lower prices (ROFIEG, 2019). The importance of the process of 'financial inclusion', i.e. increasing access to financial services, is also increasingly emphasised. Moreover, legislators and supervisors intend to raise public awareness and consumer security, especially in developing countries (Makina, 2019).

The trend of creating regulatory sandboxes has gained many supporters around the world, resulting in the creation of global initiatives, such as the Global Financial Innovation Network (hereafter: GFIN). GFIN was announced on 7 August 2018 and is bound to become a global sandbox for cross-border testing conducted by innovative companies. Currently, more than 50 organisations from all over the world are involved in the initiative, including regulators and supervisors (Clifford Chance, 2019). Sandboxes are also becoming a financial inclusion tool, as evidenced by the creation of Financial inclusion sandboxes sponsored by banks, such as the Bank of Sierra Leone and Bank Negara Malaysia. The purpose of such sandboxes is primarily financial inclusion. Their operation is justified mainly in developing countries (Duff, 2019).

1 The Bank Guarantee Fund is a Polish institution established in 1994 which guarantees deposits of banks and cooperative savings and credit unions in the amount not exceeding the PLN equivalent of EUR 100,000. 
As their experience grows, some of the countries mentioned above modify certain elements of regulatory sandboxes, especially in the area of licence types or categories of sandbox participants. Today, sandboxes in various forms are present in more than 25 countries around the world, including developing countries such as Mozambique and Sierra Leone (Columbia Institute for Tele-Information, 2020). The Spanish Council of Ministers is the latest country to announce the launch of a regulatory sandbox on 18 February 2020 (Calvo \& Howell, 2020).

\section{Methods}

Several research methods were required to achieve the objectives of the paper. The starting point was the study of Polish and international literature on the subject. Since both the development of the FinTech sector and the resulting regulatory sandboxes are new phenomena, the scientific literature in this area is still very limited. In addition, industry studies and reports from financial institutions, which contain up-to-date secondary data sources, were also consulted. The result of the theoretical considerations was our definition of a regulatory sandbox.

The paper uses the analysis of normative acts, guidelines and documents presented by financial services market supervisors. The authors' research was a case study of a regulatory sandbox in the United Kingdom established by the UK FCA. The FCA was selected for the case study due to the fact that the United Kingdom created the first sandbox in Europe (and according to some authors, in the world) and became a pioneer in the solution. Its sandbox remains one of the world's leading sandboxes located in the London financial centre. Moreover, the supervisor provides transparent information on details related to the current operation of its sandbox.

As part of the case study, two research questions were asked: (1) Do regulatory sandboxes sufficiently support the development of financial innovation? (2) What are the benefits of creating regulatory sandboxes for financial market supervisors?

The starting point for the case study was the analysis of reports and studies from the FCA. The authors then applied the method of collecting data on selected entities that participated in the regulatory sandbox. Those representative companies were selected in two stages, according to the following criteria:

- In the first stage, a preliminary analysis was carried out of all those that took part in the FCA regulatory sandbox testing in the years 2016-2019.

- In the second stage, three representatives of the regulatory sandbox participants were selected for each of the five FCA recruitment cohorts. They were then analysed in detail.

The second stage was based on the use of information and documentation collected by the authors concerning the activities of the entities participating in the sandbox. Interviews with representatives of these companies concern- 
ing various quality aspects of operating within the regulatory sandbox were also analysed. The selection of three entities from each cohort took into account the following factors:

- subjective criterion - entities with the most innovative technological solutions in various industries;

- spatial criterion - entities which after participating in the regulatory sandbox expanded into foreign markets;

- outcome criterion - entities that increased the scale of their operations after participating in the sandbox and excelled in terms of achievements and awards.

This procedure yielded 15 companies that carried out tests in the regulatory sandbox, and they were subjected to further analysis (table 1).

\section{Case study of the FCA regulatory sandbox}

\subsection{Analysis of FCA documentation and reports}

There is no doubt that the United Kingdom has been of the greatest importance for the development of regulatory sandboxes in Europe. Therefore, it is necessary to look closely at the interest that the market players themselves have given it.

The regulatory sandbox project is a kind of experiment from which conclusions are drawn based on current experience. The FCA enables companies to perform tests every six months in the form of recruitment to 'cohorts'. Each testing entity is assigned a dedicated FCA staff member to support it during the process. Both FCA-authorised and unauthorised entities may apply to the sandbox. An important stage is FCA's assessment of an entity's readiness to undertake tests within the sandbox and the innovativeness of the implemented solution.

Between 2016 and 2019, 375 applications were submitted to the regulatory sandbox, and 118 entities tested their solutions in that environment. Thus, the scale of operation of the regulating sandbox is very limited, especially as there are more than 1600 FinTechs in the UK and this number is expected to double by 2030 (Helm, T., Low, A., \& Townson, J. (Eds.). (2019). Helm et al., 2019).

In 2017, the FCA published an important Regulatory sandbox lessons learned report (FCA, 2017) which definitely helps to understand the essence and meaning of a sandbox. The FCA lists a number of conclusions from the operation of the regulatory sandbox, for instance:

- While guiding a company in the sandbox, the authority better understands the needs and operation of financial innovations and what mechanisms may hinder development.

- The FCA's continued support for the companies has contributed to the high rate of successful test completion - 75\% of the firms admitted to the first 
cohort completed the tests and $90 \%$ of these entities have continued to grow in the market. In the case of the second cohort, $77 \%$ of the admitted entities passed the tests and according to the FCA a similar percentage will continue to operate.

- The entities that obtained restricted authorisation to carry out the test are usually no longer active.

- Testing allows the companies to verify whether customers find their product attractive and what costs they would have to bear in connection with their activities.

- The firms develop their projects during testing, and the final phase which completes the testing is the preparation of the final report with conclusions and further plans.

- The FCA provides a high level of security for customers; one of the safeguards is, for example, an exit plan so that a test can be closed at any time (in one of the first two cohorts, a company exited the test early due to lack of customer interest in the product).

In April 2019, the FCA issued another document: The impact and effectiveness of innovate (FCA, 2019) which summarised five years of regulatory sandbox operation. This report may also be used by other countries to analyse the appropriateness of creating regulatory sandboxes in their jurisdictions. However, the authority is trying to indicate that a sandbox is a useful tool, which is proved by:

- the time it takes to obtain a licence, which is $40 \%$ shorter than in the standard procedure;

- the speed of creating innovative products;

- better access to investment funding - participation in the programme makes projects more credible.

The FCA rightly points out that it is too early to announce the unequivocal success of the regulatory sandbox. However, the FCA's attempt to follow innovation has attracted many players who have also been tempted by the prospect of a European passport and access to the European market.

The very fact that an entity enters the sandbox proves that its project is innovative and prospective. Many entities, such as venture capital funds or business angels, follow the actions of the most promising participants with great attention (Wonglimpiyarat, 2018). For start-ups or entities starting their activity in this area, it is also an excellent form of advertising and making their project credible.

\subsection{Analysis of companies participating in the FCA regulatory sandbox}

The individual companies participating in the FCA regulatory sandbox were examined based on primary data collected by the authors. In the first stage, the authors analysed all companies participating in sandbox cohorts. The conclusion is that what companies usually test in a regulatory sandbox are financial products 
addressed to consumers. Few institutions test their own RegTech solutions. The vast majority have expanded their offer thanks to their participation and continue to operate. Interestingly, usually smaller companies run tests in the sandbox and not large experienced corporations.

In the second stage, taking into account the above-mentioned results, the authors presented an in-depth analysis covering directly the 15 companies participating in the FCA regulatory sandbox selected under the procedure described in section 3. Table 1 shows the five cohorts supported as part of the FCA regulatory sandbox operation. In each of the cohorts, three representatives that took part in the tests in particular periods were selected. Table 1 not only contains information about the name of the company and the idea that the entity presented in the sandbox but also covers the current situation of the company.

The analysis of the solutions tested by the companies presented in table 1 allowed the authors to determine a wide range of employed technologies and dedicated services, such as: blockchain- and DLT-based payment services, InsurTech, AML solutions, mortgage transactions, and KYC verification, consumer credit, and AI-based solutions, RegTech digital identity, tokenisation, applications facilitating the use of financial services and digital inclusion. The variety of technologies and sandbox participants presented above has far-reaching consequences for financial market supervisors. It can be assumed that through its engagement in a regulatory sandbox, the supervisor gains additional knowledge about these technologies and new business models, and its employees develop essential competences. The regulatory sandbox mechanism also allows the supervisor to strengthen the dialogue with representatives of the financial sector and to see potential risks associated with new financial solutions.

\section{Discussion of results}

It should be noted (table 1) that interest in participation in the regulatory sandbox is not waning, as evidenced by the highest number of applicants to the latest, Cohort 5. The conclusion is that the results of participation in the regulatory sandbox are encouraging for new innovative players and the initiative itself should enable more players to conduct testing. The number of applications for admission to the FCA regulatory sandbox is also gradually increasing (chart 1). The case study of individual companies has yielded that the regulatory sandbox in the UK has significantly helped them to develop financial innovations and commercialise them.

The results of the authors' research correspond in this respect to the FCA (2019) report that made a general summary of the results of the regulatory sandbox, indicating that: approximately $80 \%$ of companies that have successfully completed the tests are still operating on the market, the participants in the regulatory sandbox received total funding of GBP 135 million, the sandbox has accelerated the development of financial innovation and deepened the cooperation of large entities with start-ups by approx. 50\%. 
The case study has shown that the players who took part in the regulatory sandbox presented diverse and hitherto unknown solutions. The examples are the use of intelligent sensors in flood-prone areas for insurance purposes, real-time financial market monitoring, or guaranteed loans when selling a flat. The authors carried out an analysis of individual participants of the regulatory sandbox, and it showed that no two solutions were considerably similar to each other. Many of the solutions successfully tested in the sandbox could be considered too risky in the traditional market. Moreover, the innovations tested in the sandbox attract more attention from investors, including venture capital. It reinforces the role of the sandbox in developing financial innovation.

The research carried out has yielded an answer to question Q1 - the FCA regulatory sandbox mainly supports the development of financial innovation, although it also has its weaknesses. Sandboxes allow participants to receive continuous substantive support, as well as, on average, to obtain licences faster, and resolve numerous legal doubts. Participation in the regulatory sandbox is also an additional form of promotion for these companies.

On the other hand, regulatory sandboxes are still at an early stage of development, and the support they offer is limited. A problem pointed out in the interviews by representatives of FinTech innovation implementers is the complicated and lengthy process of applying for admission to the regulatory sandbox. The very initiative of supervisors to support FinTech's innovation through the organisation of regulatory sandboxes deserves praise for its ability to meet the needs of the financial market.

As far as research question Q2 is concerned, the research carried out has shown that the regulatory sandbox also has many benefits for the supervisory institution itself. The most important of these are:

- the opportunity to supervise the development of the innovations being tested on an ongoing basis;

- the development of competences of the supervisory institution and its employees;

- the understanding of market needs and a dialogue with professional financial market participants;

- ongoing analysis and assessment of the risks associated with new technologies;

- support for the development of the financial market and competitiveness in the financial services market.

However, the completed case study has revealed some weaknesses of the sandbox in the United Kingdom resulting from the supervisor's assumptions and methods of operation. One of them is the ability to apply for admission to the sandbox only at a certain moment, i.e. in a given cohort. Recruitment to cohorts usually starts every six months. This means that an entity that has an innovative idea and wants to test it in a sandbox is obliged to do so at a specified time. However, FinTech's dynamic growth makes the waiting period too long. The conclusions from interviews with representatives of the companies included in the case study (table l) point to the extended application process 
and high application requirements. Some of the participants also complained about the very long preparation period preceding the tests in the regulatory sandbox (Chundi, 2018). Usually, however, the companies praised the FCA for its professionalism and the help they received in the sandbox (Buzzacott, 2020; Chundi, 2018; Deloitte, 2018).

It is highly significant that the number of companies applying for the regulatory sandbox is much higher than the number of those conducting tests. There is a risk that a substantial number of entities that should be qualified will not be included in the sandbox due to insufficient resources of the supervisor that operates it and provides qualified consultants for the participating companies. It may mean that those entities will have to go through the traditional path of applying for a licence and approval to operate. Thus, the participants in the regulatory sandbox gain a more favourable competitive position. On the other hand, the refusal to include a company in the sandbox may be justified. It may be based on the necessary requirements imposed on the entities by the supervisors or the identified risks related to the immaturity of the submitted solutions. However, this problem requires further in-depth research.

\section{Conclusion}

After nearly five years of regulatory sandbox operation, interest in their creation by global supervisors and regulators continues. Sandboxes are constantly gaining popularity, especially as they effectively support the development of many innovative solutions in the financial services market.

The case study of the regulatory sandbox in the United Kingdom presents the mechanisms of the first regulatory sandbox in Europe. In total, 118 out of 375 applicants were tested in the sandbox. The outcomes of the FCA regulatory sandbox proved to be encouraging for new entrants, with the greatest interest recorded in the most recent period of its operation. An additional advantage of sandboxes is the possibility to test innovations in a safe, isolated environment, which allows both to verify the business model on the part of the entrepreneur and to ensure the security of consumers.

The regulatory sandbox allows for the development of different technologies at the same time. Besides, the FCA sandbox is characterised by its versatility. Tested solutions cover many industries: from banking, insurance, through payments, to solutions improving the work of institutions through RegTech. The FCA continuously supports all testing companies. It ensures that the participants know in which direction their business model should be developed. An additional benefit of participating in the sandbox is better recognition and easier access to capital.

The regulators and supervisors also benefit from the solution, as they continuously observe the market and support the entities testing in the sandbox. The development of regulatory sandbox allows them to understand how new technologies are developing and how they affect the growth and security of the fi- 
nancial market. It can be done directly by developing technological solutions for supervisory institutions, the so-called SupTech. On the other hand, the regulatory sandbox allows for testing a somewhat limited number of entities. It may, therefore, not have sufficient impact on the development of financial innovation and potentially distort competition on the FinTech market.

However, it should be stressed that regulatory sandboxes are praised by their participants and provide opportunities for accelerated development of financial innovation. There is no doubt that a sandbox is a tool supporting the development of innovation; other tools, such as chatrooms, the Innovation Hub, acceleration programmes, and others, are also constantly being developed. It seems that the development of innovation in the financial market is of great importance and can count on the support of regulators and supervisors.

However, one should not forget about the role in the development of innovation played by the largest corporations such as Google, Amazon, Facebook, or Apple (the popular acronym GAFA). Due to their vast capital resources and global customer base, they can afford to run tests of FinTech solutions on their own or in collaboration with start-ups, without involvement in regulatory sandboxes. GAFA has already achieved a strong position in selected financial services, e.g. mobile payments. Does the question arise whether the biggest challenge for traditional banking will come from big corporations rather than the agile startups? Undoubtedly, this issue is essential for the development of the financial market and should, therefore, become the subject of future studies.

\section{References}

1818 Venture Capital Fund. (2020). Asset vault. Retrieved 17.05.2020 from https://1818venturecapital.com.

Alt, R., Beck, R., \& Smits, M.T. (2018). FinTech and the transformation of the financial industry. Electronic Markets, 28(3). doi:10.1007/s12525-018-0310-9.

BFG. (2019). Zasady gwarantowania depozytów. Retrieved 20.02.2020 from https://www.bfg.pl.

Billon. (2019). Billon uzyskat pierwszą w Polsce licencję pieniądza elektronicznego. Retrieved 20.06.2020 from https://billongroup.com.

Blink. (2020). Retrieved 25.02.2020 from https://blinkblink.io.

British Heart Foundation. (2020). Retrieved 21.06.2020 from https://www. bhf.org.uk.

Bunea, S., Kogan, B., \& Stolin, D. (2016). Bank vs. Fintech: at last, it's official. Journal of Financial Transformation, 44

Buzzacott. (2020). Billon graduates from the sandbox with flying colours. Retrieved 19.05.2020 from https://www.buzzacott.co.uk.

Calvo, A., \& Howell, J.L.L. (2020). Spain approves the legislative proposal that implements a regulatory sandbox. Retrieved 24.02.2020 from https://www. lexology.com. 
CFPB. (2012). CFPB launches project catalyst to spur consumer-friendly innovation. Retrieved 22.02.2020 from https://www.consumerfinance.gov.

Chundi, V. (2018). UK FCA regulatory sandbox: lessons learnt and application tips. Retrieved 17.05.2020 from https://medium.com.

Chynge. (2020). Retrieved 25.02.2020 from https://chynge.com.

Clifford Chance. (2019). Global financial innovation network launched: hopes to boost Fintech growth. Retrieved 17.02.2020 from https://talkingtech.cliffordchance.com.

Columbia Institute for Tele-Information. (2020). Retrieved 23.02.2020 from https://dfsobservatory.com.

CommonBond. (2020). Retrieved 18.02.2020 from https://www.commonbond.co.

Dashly. (2020). Testing, testing, testing: Dashly accepted into the 4th cohort of the FCA's regulatory sandbox. Retrieved 21.06.2020 from https://dashly. com.

De Brauw Blackstone Westbroek. (2016). DNB and the AFM create regulatory sandbox. Retrieved 18.02.2020 from https://www.debrauw.com.

Deloitte. (2018). A journey through the FCA regulatory sandbox: the benefits, challenges, and next steps. Retrieved 19.05.2020 from https://www2.deloitte. com.

Du, W., Pan, S.L., Leidner, D.E., \& Ying, W. (2019). Affordances, experimentation and actualization of FinTech: a blockchain implementation study. The Journal of Strategic Information Systems, 28(1). doi:10.1016/j.jsis.2018.10.002.

Duff, S. (2019). A growing trend in financial regulation: thematic sandboxes. Retrieved 27.02.2020 from https://www.cgap.org.

EBA. (2017). Discussion paper on the EBA's approach to financial technology (FinTech). Retrieved 17.02.2020 from https://eba.europa.eu.

FCA. (2015). Regulatory sandbox: November. Retrieved 18.02.2020 from https:// www.fca.org.uk.

FCA. (2017). Regulatory sandbox lessons learned report. Retrieved 25.02.2020 from https://www.fca.org.uk.

FCA. (2018). Regulatory sandbox: cohort 3. Retrieved 21.06.2020 from https:// www.fca.org.uk.

FCA. (2019). The impact and effectiveness of innovate. Retrieved 25.02.2020 from https://www.fca.org.uk.

FCA. (2020). Regulatory sandbox. Retrieved 18.06.2020 from https://www.fca. org.uk.

FloodFlash. (2020). Retrieved 27.02.2020 from https: / floodflash.co.

FSB. (2020). Monitoring of FinTech. Retrieved 17.02.2020 from https://www. fsb.org.

Gai, K., Qiu, M., \& Sun, X. (2018). A survey on FinTech. Journal of Network and Computer Applications, 103. doi:10.1016/j.jnca.2017.10.011.

Guo, Y., \& Liang, C. (2016). Blockchain application and outlook in the banking industry. Financial Innovation, 2(1). doi:10.1186/s40854-016-0034-9. 
Harasim, J., \& Mitręga-Niestrój, K. (2018). FinTech: dylematy definicyjne i determinanty rozwoju. Prace Naukowe Uniwersytetu Ekonomicznego we Wroctawiu, 531. doi:10.15611/pn.2018.531.15.

Helm, T., Low, A., \& Townson, J. (Eds.). (2019). UK FinTech: state of the nation. Retrieved 19.05.2020 from https://gov.uk.

Jagtiani, J., \& Lemieux, C. (2018). Do fintech lenders penetrate areas that are underserved by traditional banks. Journal of Economics and Business, 100. doi:10.1016/j.jeconbus.2018.03.001.

Jenik, I., \& Lauer, K. (2017). Regulatory sandboxes and financial inclusion. CGAP Working Paper, October.

Junglas, I.A., \& Steel, D.J. (2007). The virtual sandbox. ACM SIGMIS Database, 38(4). doi:10.1145/1314234.1314240.

KNF. (2020). Aktualności FinTech. Retrieved 17.02.2020 from https://www. knf.gov.pl.

L\&C Mortgages Limited. (2020). Retrieved 21.06.2020 from https://www. landc.co.uk.

Laahanen, S., \& Yrjänä, E. (2019). FinTechs: their value promises and disruptive potential. ACRN Oxford Journal of Finance and Risk Perspectives, 8(2).

Makina, D. (2019). The potential of FinTech in enabling financial inclusion. In D. Makina (Ed.), Extending financial inclusion in Africa. London: Academic Press. doi:10.1016/B978-0-12-814164-9.00014-1.

Marchewka-Bartkowiak, K. (2019). Regulacyjne środowisko testowe (regulatory sandbox): doświadczenia i perspektywy. Studia BAS, 1(57). doi:10.31268/ studiabas.2019.04.

Marchewka-Bartkowiak, K. (2020). Rola piaskownic regulacyjnych w ograniczaniu ryzyka prawnego sektora FinTech. In E. Miklaszewska, \& M. Folwarski (Eds.), Bankowość emocjonalna: cyfrowa transformacja banków a oczekiwania klientów. Warszawa: Poltext.

McAuley, D. (2015). What is FinTech. Retrieved 16.05.2020 from https://medium.com.

Mettle. (2020). Retrieved 21.06.2020 from https://www.mettle.co.uk.

Monergie. (2020). Retrieved 21.06.2020 from https://www.monergie.com.

Moneyhub Enterprise. (2020). Our awards. Retrieved 25.02.2020 from https:// www.moneyhubenterprise.com.

Nested. (2020). Retrieved 27.02.2020 from https://nested.com.

NorthRow. (2018). NorthRow selected for the FCA's regulatory sandbox. Retrieved 21.06.2020 from https://www.northrow.com.

Ocio, S., \& Brugos, J.A. (2009). Multi-agent systems and sandbox games. In N.K. Taylor (Ed.), Adaptive and emergent behaviour and complex systems: proceedings of the 23rd convention of the Society for the Study of Artificial Intelligence and Simulation of Behaviour. Edinburgh: Society for the Study of Artificial Intelligence and the Simulation of Behaviour.

Philippon, T. (2016). The Fintech opportunity. NBER Working Paper, 22476. doi:10.3386/w22476. 
Polasik, M., \& Piotrowski, D. (2016). Payment innovations in Poland: a new approach of the banking sector to introducing payment solutions. Ekonomia $i$ Prawo. Economics and Law, 15(1). doi:10.12775/eip.2016.007.

Ringe, W.G., \& Rouf, C. (2018). A regulatory sandbox for robo advice. European Banking Institute Working Paper Series, 26. doi:10.2139/ssrn.3188828.

ROFIEG. (2019). 30 recommendations on regulation, innovation and finance. Retrieved 18.03.2020 from https://ec.europa.eu.

Romanova, I., Grima, S., Spiteri, J., \& Kudinska, M. (2018). The Payment Services Directive II and competitiveness: the perspective of European Fintech companies. European Research Studies Journal, 21(2). doi:10.35808/ersj/981.

Spherical Defence. (2020). About us. Retrieved 25.02.2020 from https:// sphericaldefence.com.

Szpringer, W. (2016). Fin-Tech: nowe zjawisko na rynku usług finansowych. E-mentor, 2(64). doi:10.15219/em64.1240.

Wonglimpiyarat, J. (2018). Challenges and dynamics of FinTech crowd funding: an innovation system approach. Journal of High Technology Management Research, 29(1). doi:10.1016/j.hitech.2018.04.009.

\section{Acknowledgements}

Author contributions: authors have given an approval to the final version of the article. Authors contributed to this work as follows: A.B-K. \& M.P. developed the concept and designed the study, A.B-K. collected the data, A.B-K. \& M.P. analysed and interpreted the data, A.B-K. \& M.P. prepared draft of article, A.B-K. \& M.P. revised the article critically for important intellectual content.

Funding: this research was supported by the National Science Centre of Poland under grant (2017/26/E/HS4/00858).

Disclaimer: The views expressed in the article are the personal views of the Author Agnieszka Butor-Keler and do not express the official position of the institution which she is employed by. 


\section{Appendix}

Table 1.

\section{Qualification results to the FCA regulatory sandbox and selected cases of accepted companies by cohort}

\begin{tabular}{|c|c|c|}
\hline Number of applicants & Number of applications accepted & Number of qualified companies \\
\hline \multicolumn{3}{|c|}{ Cohort l (2016) } \\
\hline 69 applications & 24 applications (35\%) & 18 companies $(26 \%)$ \\
\hline \multicolumn{3}{|c|}{ Examples of solutions tested by companies from a given cohort and current activity } \\
\hline \multirow{3}{*}{$\begin{array}{l}\text { Name of the company: Billon } \\
\text { Product: an electronic money plat- } \\
\text { form based on Distributed Ledger } \\
\text { Technology (DLT); }\end{array}$} & \multirow{2}{*}{$\begin{array}{l}\text { Name of the company: Blink Inno- } \\
\text { vation Limited }\end{array}$} & \multirow{2}{*}{$\begin{array}{l}\text { Name of the company: Nextday } \\
\text { Property Limited }\end{array}$} \\
\hline & & \\
\hline & \multirow{3}{*}{$\begin{array}{l}\text { Product: an InsurTech company. } \\
\text { The application monitors airplane } \\
\text { delays or cancellations, and if such } \\
\text { occur it: gives access to the airport } \\
\text { lounge (or transfers a certain } \\
\text { amount of money), books a hotel } \\
\text { room (in the case of lack of available } \\
\text { seats it refunds a certain amount } \\
\text { of money), and then books a new } \\
\text { flight. }\end{array}$} & \multirow{2}{*}{$\begin{array}{l}\text { Product: a London-based real } \\
\text { property agency which, if customers } \\
\text { do not sell their property within } 90 \\
\text { days, grants them an interest-free } \\
\text { loan for a predetermined and guar- } \\
\text { anteed amount. }\end{array}$} \\
\hline \multirow{3}{*}{$\begin{array}{l}\text { Current situation: Billon started its } \\
\text { activity also in Poland, where it was } \\
\text { the first entity to obtain a licence } \\
\text { of an electronic money institution } \\
\text { (Billon, 2019). }\end{array}$} & & \\
\hline & & \multirow{2}{*}{$\begin{array}{l}\text { Current situation: the company is } \\
\text { gradually growing. It also offers } \\
\text { the possibility of constant moni- } \\
\text { toring of interest in the property, } \\
\text { regular consultancy of the account } \\
\text { manager and it can conduct negotia- } \\
\text { tions on behalf of the client (Nested, } \\
2020 \text { ). }\end{array}$} \\
\hline & $\begin{array}{l}\text { Current situation: the entity was } \\
\text { acquired by CPP Group (AIM CPP) } \\
\text { in March 2017. It operates world- } \\
\text { wide (Blink, 2020). }\end{array}$ & \\
\hline \multicolumn{3}{|c|}{ Cohort 2 (2017) } \\
\hline \multirow[b]{2}{*}{77 applications } & 31 applications (40\%) & \multirow[b]{2}{*}{24 companies (31\%) } \\
\hline & $\begin{array}{l}7 \text { companies were not ready for } \\
\text { testing }\end{array}$ & \\
\hline \multicolumn{3}{|c|}{ Examples of solutions tested by companies from a given cohort and current activity } \\
\hline \multirow{5}{*}{$\begin{array}{l}\text { Name of the company: FloodFlash } \\
\text { Product: FloodFlash is a company } \\
\text { that operates in the InsurTech area. } \\
\text { It provides flood insurance even } \\
\text { in high-risk areas which could pre- } \\
\text { viously be excluded from insurance. } \\
\text { The presented solution is equipped } \\
\text { with a sensor that monitors whether } \\
\text { the water level has exceeded } \\
\text { a certain height. In such a case, it is } \\
\text { the basis for compensation. }\end{array}$} & \multirow{2}{*}{$\begin{array}{l}\text { Name of the company: Moneyhub } \\
\text { Enterprise }\end{array}$} & \multirow[t]{2}{*}{ Name of the company: } \\
\hline & & \\
\hline & \multirow{2}{*}{$\begin{array}{l}\text { Product: a tool that combines several } \\
\text { technologies: AI, data analysis. } \\
\text { It promotes positive patterns for } \\
\text { consumers in the area of financial } \\
\text { services and offers services for } \\
\text { traders that help them understand } \\
\text { customers' needs. }\end{array}$} & $\begin{array}{l}\text { Product: it allows both physical } \\
\text { and digital resources to be cata- } \\
\text { logued in one secure register. }\end{array}$ \\
\hline & & \multirow{3}{*}{$\begin{array}{l}\text { Current situation: the company is } \\
\text { expanding its business. This entity } \\
\text { received additional funding through } \\
1818 \text { Venture Capital Fund (2020). }\end{array}$} \\
\hline & \multirow{2}{*}{$\begin{array}{l}\text { Current situation: the winner } \\
\text { of many awards, including The most } \\
\text { innovative new product using account } \\
\text { aggregation for making consumer lives } \\
\text { better, FDATA Global Awards } 2019 \\
\text { (Moneyhub Enterprise, 2020). }\end{array}$} & \\
\hline $\begin{array}{l}\text { Current situation: the company } \\
\text { operates in the United Kingdom } \\
\text { and has both individual and institu- } \\
\text { tional clients (FloodFlash, 2020). }\end{array}$ & & \\
\hline
\end{tabular}




\begin{tabular}{|c|c|c|}
\hline Number of applicants & Number of applications accepted & Number of qualified companies \\
\hline \multicolumn{3}{|c|}{ Examples of solutions tested by companies from a given cohort and current activity } \\
\hline \multicolumn{3}{|c|}{ Cohort $3(2017)$} \\
\hline 61 applications & 18 applications (29.5\%) & 18 companies $(29.5 \%)$ \\
\hline \multicolumn{3}{|c|}{ Examples of solutions tested by companies from a given cohort and current activity } \\
\hline Name of the company: Barclays & Name of the company: Spherical & Name of the company: Chynge \\
\hline Product: a RegTech solution which & Defence Labs & \multirow{4}{*}{$\begin{array}{l}\text { Product: digital payment system, } \\
\text { based on the DLT technology. The } \\
\text { system monitors the transaction } \\
\text { through AI and a virtual bot which } \\
\text { verify transfers in accordance with } \\
\text { AML and counter-terrorist financ- } \\
\text { ing policies. } \\
\text { Current situation: the company has } \\
\text { expanded its activities and is also su- } \\
\text { pervised by the Monetary Authority } \\
\text { of Singapore (Chynge, 2020). }\end{array}$} \\
\hline $\begin{array}{l}\text { adapts and implements the current } \\
\text { and revised FCA regulations to Bar- } \\
\text { clays' internal rules on an ongoing } \\
\text { basis. }\end{array}$ & $\begin{array}{l}\text { Product: API security system which } \\
\text { aims to ensure the security of banks } \\
\text { by detecting attacks and security } \\
\text { breaches. }\end{array}$ & \\
\hline $\begin{array}{l}\text { Current situation: as a global } \\
\text { financial services provider, Barclays }\end{array}$ & $\begin{array}{l}\text { Current situation: a solution based } \\
\text { on machine learning. This entity has }\end{array}$ & \\
\hline $\begin{array}{l}\text { optimises the processes of adapting } \\
\text { supervisory regulations to its } \\
\text { business. Barclays also took part } \\
\text { in cohort } 5 \text { (FCA, 2018). }\end{array}$ & $\begin{array}{l}\text { also been invited to the Government } \\
\text { (GCHQnications Headquarters } \\
\text { (Spherical Defence, 2020). }\end{array}$ & \\
\hline \multicolumn{3}{|c|}{ Cohort $4(2018)$} \\
\hline 69 applications & $\begin{array}{l}29 \text { companies, representing } 42 \% \\
\text { of the applications, were accepted } \\
\text { for development towards testing, } \\
\text { including } 3 \text { companies that were } \\
\text { accepted under the previous cohorts } \\
\text { but did not start testing }\end{array}$ & $\begin{array}{l}29 \text { companies, representing } 42 \% \\
\text { of the applications, were accepted } \\
\text { for development towards testing, } \\
\text { including } 3 \text { companies that were } \\
\text { accepted under the previous cohorts } \\
\text { but did not start testing }\end{array}$ \\
\hline
\end{tabular}

Examples of solutions tested by companies from a given cohort and current activity

Name of the company: Dashly

Product: a mortgage advisory platform which analyses and observes current trends and conditions of mortgages on the market and alerts the borrower to the possibility of changing the loan to one with more favourable conditions.

Current situation: the application constantly monitors market transactions and also analyses the individual situation of the client, e.g. early repayment commission, change in value of the property. The aim is to adapt to individual customer needs (Dashly, 2020).

\section{Name of the company: Mettle}

Product: free current account addressed to small businesses. The solution offers support for entrepreneurs, accounting services and dedicated applications e.g. for invoicing.

Current situation: a solution aimed at small businesses, helps, e.g., to organise and categorise payments (Mettle, 2020).

\section{Name of the company: NorthRow}

Product: a solution based on process optimisation, including process implementation and ensuring compliance with KYC and AML requirements.

Current situation: the company was founded in 2010 and is now a technology partner for many supervised entities (NorthRow, 2018).

Cohort 5 (2019)

99 applications 29 applications (29\%) 29 companies (29\%)

Examples of solutions tested by companies from a given cohort and current activity

Name of the company: L\&C Mort- Name of the company: Monergie gages Limited

Product: a platform that is dedicated to customers for mortgage transactions.

Current situation: the platform offers several types of services: from the purchase of the first house to re-mortgage (L\&C Mortgages Limited, 2020).
Product: a solution dedicated to companies which give their employees the option to receive advance pay at any time of work.

Current situation: employees using the service can also use the platform in the area of financial education (Monergie, 2020).
Name of the company: British Heart Foundation

Product: solution implemented by a charity, offering travel insurance extended by medical examinations for a group of consumers suffering from cardiovascular diseases.

Current situation: the foundation is actively working to the benefit of people with heart diseases (British Heart Foundation, 2020). 


\begin{tabular}{ccc}
\hline Number of applicants & Number of applications accepted & Number of qualified companies \\
\hline & Cohort 6 is currently under evaluation & \\
\hline 375 & Total & 118 \\
\hline
\end{tabular}

Source: Own preparation based on FCA (2020).

\section{Chart 1.}

Number of participants in the FCA regulatory sandbox within each cohort

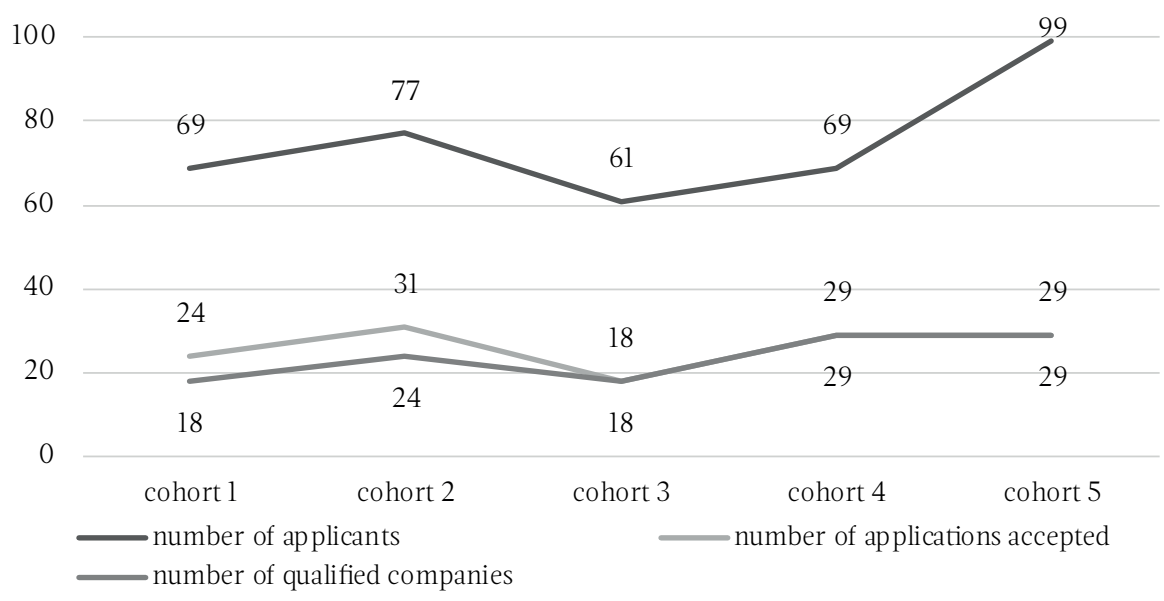

Source: Own preparation based on FCA (2020). 